\title{
Application of the Art. 58 of UN Convention on the International Sale of Goods (CISG)
}

\author{
Xiang $\mathrm{LI}^{1, \mathrm{a},{ }^{*}}$ \\ ${ }^{1}$ Nanjing University of Science and Technology, China \\ a18251950531@163.com \\ ${ }^{*}$ Corresponding author
}

Keywords: CISG, Obligations of the Buyers, Time to Pay the Price, Right to Examine the Goods.

\begin{abstract}
The Art. 58 of UN Convention on the International Sale of Goods (hereinafter referred to briefly as CISG) provides the issue that when the buyer is bound to pay to the seller during the performance of the contract. It also provides when the buyer's right to inspect conflicts with his payment obligations, how to handle it. These provide a legal basis for sellers and buyers to fulfill their obligations better, and to avoid adding the contract dispute to both parties due to a loophole in the law.
\end{abstract}

\section{Introduction}

It is important to clear the time for the buyer to pay the price. On the one hand, the payment time can definitely determine whether there is a fundamental breach by the buyer, then to determine whether the seller was entitled to apply for the contract of invalid. In General, if the buyer fails to fulfill the obligation to pay the purchase price within the stipulated time, it does not necessarily constitute a fundamental breach. Only at the end of the grace period granted by the seller or by the buyer to fulfill payment obligations will constitute a fundamental breach. On the other hand, payment time determines the time the seller's claiming for payment and the first day to calculate the interest on defaulted loans by the seller. When the buyer fails to fulfill its payment obligations on time, the seller may exercise their right to a payment request, and as well as the loss of interest on defaulted loans.

\section{Summary of the Art. 58 of CISG}

\section{Contents}

The Art. 58 of CISG is in the system of the buyers' obligations. It mainly introduced the time that the buyer is bound to pay to the seller and the solution when the buyer's right to inspect conflicts with his payment obligations.

Art. 58th as follows:

- If the buyer is not bound to pay the price at any other specific time, he must pay it when the seller places either the goods or documents controlling their disposition at the buyer's disposal in accordance with the contract and this Convention. The seller may make such payment a condition for handing over the goods or documents.

- If the contract involves carriage of the goods, the seller may dispatch the goods on terms whereby the goods, or documents controlling their disposition, will not be handed over to the buyer except against payment of the price. 
- The buyer is not bound to pay the price until he has had an opportunity to examine the goods, unless the procedures for delivery or payment agreed upon by the parties are inconsistent with his having such an opportunity.

\section{Application}

The Art. 58 can only be applied in the condition that there is no stipulation of the time to pay the price in the contract. If specific payment schedule is agreed in the contract or according to the buyers and sellers trading habits, there is a default of payment, then, of course, we should exclude the application of the Art.58.

\section{Time to Fulfill Payment Obligation}

\section{Payment Time not Involved in the Transit}

The item 1 of Art.58 requires the buyer to pay the purchase price of the goods when the seller gives the document of controlling goods to the buyer. If the buyer did not pay the price during this time, the seller may refuse to deliver the goods or the documents. The seller can put the buyer to pay the price as a condition for handing over the goods or documents. Conversely, if the seller had not fulfilled its delivery obligation, the buyer may refuse to fulfill their obligation for payment.

This item is similar to the counterargument right for simultaneous performance introduced in the Art. 66 of the Contract Law. One part can reject to fulfill its obligation before the other part performing its duty. When one part does not fulfill its obligation in accordance with the contract and the Covention, the other one can eject to fulfill its obligation as well. In the article of the CISG, if the contract does not specify the time of the payment and there is no stipulation of the order of the buyer's obligation to pay and the seller's obligation to deliver the order, the buyer and the seller should fulfill their obligation at the same time. If the buyer did not pay the price during this time, the seller may refuse to deliver the goods or the documents. Conversely, if the seller had not fulfilled its delivery obligation, the buyer may refuse to fulfill their obligation for payment.

When applying the provisions of this article in practice, one should also pay highly attention. There is complexity in international trade. Specific time of payment will vary depending on the mode of delivery by the seller. For example, if agreed trade term by the seller and the buyer is the EXW, ex works, then the buyer is obliged to deliver the goods at the seller's place of business or place of storage of goods. In this condition, the buyer's time for payment is when the seller transfers the goods under the contract, and when you take delivery of notice to the buyer, upon receipt of notice of a reasonable period of time to receive the goods and pay the price. Meanwhile, according to the provisions of Art. 58, the buyer has the right to enter the warehouse to inspect goods before paying to the buyer. The seller should provide convenient for exercising that obligation. If agreed trade term by the seller and the buyer is DES, that is, FOB destination, in which case the buyer payment time is when the seller has shipped the goods to the port terminals, and after taking delivery of notice to the buyer, within a reasonable time after receipt of notice to take delivery and pay the price. Similarly, the buyer had the right to examine the goods before the payment. Thus, with different modes of delivery, time of the buyer to pay the price of is also different. 


\section{Payment Time Involved in the Transit}

CISG Art. 58 introduce the payment time when the contract involves in the transit, which set in the presence of a wide range of international trade. In those contracts involving in the carriage, when the seller completes its delivery obligations, it also involves an independent carrier. In this condition, the delivery needs to be completed in three stages. Generally, it includes the seller to ship the goods at the port of shipment (ready delivery), the seller to make delivery to the buyer and the carrier to deliver the goods to the buyer at the port of destination. So in the contract involves carriage, which stage should the buyer make the payment?

Here, we use the case of New Zealand raw wool as an example. Plaintiff is a New Zealand company that exported wool, while the defendant is a company that imported wool in Tianjin, China. The seller and the buyer were introduced to enter into a contract of 200 tons of raw wool in May 15th, 1997. The total amount is $\$ 719,000.00$. They agreed to in ship the goods in June 1997. During the period from June to September, 1997, the buyer did not open the letter of credit. After September 20th, 1997 , the price of raw wool began to fall continuously. In order to mitigate its loss, the seller then resold the raw wool under the contract. In March 26th, 1998, the seller claimed in a fax: due to damage brought to the seller caused by the buyer's breach of contract, the seller declared the contract invalid and sought compensation from the buyer for the losses. In May 28th, 1998, the seller filed for arbitration to the arbitration bodies, requiring the buyer to pay for the damage.

In this case, the buyer thinks he should fulfill the obligation of paying the price in second stage. So he did not open the letter of credit because the seller did not fulfill its obligations in the first phase. While the seller believed that according to the CISG the 58th, as the contract involves carriage of the goods, the seller may give the document of controlling goods to the buyer after the buyer paying the price. He believed that the first stage of shipping the goods at the port was the behavior the Art. 58 involved. So, the seller thought the buyer to fulfill the obligation of paying the price at the first stage.

In this case, there are different understandings between the buyer and the seller of the word "shipment". I think it refers to the second phase. Because in the first stage, it is unreasonable to require the buyer to pay the price upon the goods are handed over to the carrier. Because at this point, the goods has not been delivered to the buyer. It is not in our normal business practices to require the seller to pay the price without seeing the goods or the documents of controlling goods. In the second stage, it is reasonable to require the buyer to pay the purchase price when documents are sent to him.

But at this point, the goods have been handed over to the carrier, either en route or already delivered to buyer's place. If the goods are denied or the buyer rejected to pay the price, the seller will suffer a huge loss of transport costs and other transaction costs. So how can the seller avoid such risks?

The item 2 of the Art. 58 introduces the extra condition which is only when the buyer pays the price to the seller will the seller send the document of controlling goods. Only the buyer accepts this condition will the seller delivers the goods. Requiring the buyer to open a letter of credit is to satisfy this condition. The seller informed the negotiating bank for payment orders. After the purchaser open a letter of credit to require the negotiating bank to pay in advance, the buyer pays the bank. So, the process of negotiating bank foreclosure from the seller's is the procession the buyer paying the price. In addition, after handing over the goods to admitted person, if 
the buyer does not pay the price in accordance with the agreed time of payment, the seller can find the buyer's breach of the contract and claim damages for their losses.

\section{Pay Obligation and Examine Right}

The provision of third item of the Art. 58 addresses that the buyer is not bound to pay the price until he has had an opportunity to examine the goods, unless the procedures for delivery or payment agreed upon by the parties are inconsistent with his having such an opportunity.

\section{Paying Obligation not Contract to Examine Right}

If the buyer the opportunity to inspect the goods before the payment is not in contradiction with the agreement on delivery and payment arrangements between two parties, the buyer has the right to inspect the goods before the payment. At the same time, the seller has an obligation to provide the opportunity of inspection to the buyer before the buyer paying the price and shall not prevent the purchaser exercising that right.

When the contract does not involve in an independent carrier, where transactions require the buyer to be responsible for shipping or use their own transport carriers, the buyer is a way of the opportunity to examine the goods before payment; or when the two parties agreed to use the trade term of DES, the carrier is responsible for the transportation of the goods, seller may indicate the carrier to allow the buyer to examine the goods before the payment after arrival of the goods.

\section{Paying Obligation Contracts to Examine Right}

In what circumstances will a buyer's opportunity of inspecting the goods be in contraction to the procedures for delivery or payment agreed upon both parties?

If both party agreed to use the trade term of CIF, the payment is in the condition of the delivery of the documents. After the seller shipment goods and get the documents from the carrier, he can require the buyer to make the payment by giving the documents to him. When the bank tips the buyer of documents to send the requests of payment, the goods may have not arrived at the destination port yet. This belongs to the situation that that the paying obligation of the buyer contracts to the right to examine the goods. At this time, the buyer cannot examine the goods before fulfilling the obligation of paying the purchase price.

\section{Examine Right not Contract to Art. 38 of CISG}

Art. 38 as follows:

- The buyer must examine the goods, or cause them to be examined, within as short a period as is practicable in the circumstances.

- If the contract involves carriage of the goods, examination may be deferred until after the goods have arrived at their destination.

- If the goods are redirected in transit or redispatched by the buyer without a reasonable opportunity for examination by him and at the time of the conclusion of the contract the seller knew or ought to have known of the possibility of such redirection or redispatch, examination may be deferred until after the goods have arrived at the new destination.

No matter if the buyer has the opportunities of inspecting the goods, his right to examine the goods introduced in Art. 38 are not affected. That is, if buyer inspected the goods before making the payment, he still has the right of inspection. If buyer 
does not have the opportunity for inspection, he can also examine the goods according to the Art.38 and require compensation on those goods do not meet contract requirements.

\section{Conclusions}

Many complex disputes lies ultimately in the lack of a clear definition of the rights and obligations of the buyer and seller and how to exercise. On one hand, the resolution of this issue depends on terms of the improvement of the contract. It means the two parties should provide details of the contract as completed as possible so that they all have a clear understanding of each other's rights and obligations. On the other hand, the ability of foresight for human being is limited. It is impossible to anticipate all of things, which requires the parties to have a correct understanding of supplemental features of the law. Empirical test

\section{References}

[1] Ratko Brnabić. Contractual parties' right to postpone obligations and the seller's right to stop goods being transported according to the United Nations' Convention on Contracts for the International Sale of Goods. [J]. Collected papers of the faculy of law in Split, 2012, Vol.49 (1)

[2] Schlechtriem, Peter, and G. Thomas. "Commentary on the UN Convention on the International Sale of Goods (CISG)." Commentary on the Un Convention on the International Sale of Goods 31.1(2005):166-169.

[3] Davies, Martin, and LLM (Harvard). "Documents That Satisfy the Requirements of CISG Art. 58." (2011).

[4] Andersen, Camilla Baasch. "General Principles of the CISG -- Generally Impenetrable?." Current Opinion in Cell Biology 10.10(1998):131-9. 